\title{
THE EFFECT OF COOPERATIVE LEARNING ON STUDENTS' ECOLOGY ACHIEVEMENT AND INTERPERSONAL COMMUNICATION SKILL IN BIOLOGY EDUCATION STUDY PROGAM FKIP PAKUAN UNIVERSITY BOGOR
}

\author{
Indri Yani ${ }^{a *}$ \\ a) Pakuan University, Bogor, Indonesia \\ *) Corresponding Author: indri@unpak.ac.id
}

Article history: received 19 August 2019; revised 31 August 2019; accepted 16 September2019

\begin{abstract}
This research is aimed at finding out the effect of cooperative learning on students' achievement in ecology and their interpersonal communication skill in Biology Education Study Program, FKIP Unpak Bogor. This research was conducted at Biology Education Study Program, FKIP Unpak Bogor, and academic year of 2017/2018. Population in this research is students of the fourth semester of Biology Education Study Program, FKIP Unpak Bogor. Cluster Random Sampling technique is used in choosing the sample. There are two classes chosen as the sample with 75 students. Quantitative approach is used with experimental method which consists of three variables. The first variable is Team Assisted Individualization model (TAI) which is a independent variable (X). The second variable consists of two dependent variables (Y) they are ecology learning achievement and interpersonal communication skill. Based on the data analysis and research result, it can be concluded that there is an effect of the use of Team Assisted Individualization model on ecology learning achievement in Biology Education Study Program, FKIP Unpak Bogor. Learning outcome of ecology and interpersonal communication skill on experimental group which taught using Team Assisted Individualization is better than the result of the control group. Team Assisted Individualization model is a model that can improve ecology learning outcome and interpersonal communication skill.
\end{abstract}

Keywords: team assisted individualization model; interpersonal communication skill

\section{INTRODUCTION}

During ecucation process mistakes are commonly occur, it is because the lack in communcation system. Communication system that is used at classroom commonly is a one way communication, in this type of communication teachers serve the role as instructor in which they play a more active role than the students. This type of communication could encrourage students effectively during teaching learning process. Educational communication addressed in this paper is the relationship or interaction between teacher and students or among during teaching learning process. In another word, the active relationship between teacher and students or among students themselves.

There is a continous information exchange process in communication, exchange of opinion, and attitude as the basic adjustment between students and teacher or among students. There should be a two way communications on both sides, therefore a cooperation is needed in order to achieve learning goals. A good frequency and intensity of communication can improve learning achievement, and on the contrary a bad one can result in bad relationship. Different opinion and others may affect on learning achievement.

Learning strategy that can actively involved students emphasize on the process as well as the achivement. It means that students are expected to be able to build knowledge in learning actively and indivudually. One of the strategy that involved students actively is cooperative learning.

Teachers give opportunity to students to express their opinion, listen to opinion, and together with other students discuss problems given by the teacher in cooperative learning process. In deciding learning strategy teahcer must considers many aspects, such as students conditions, school condition, supporting learning environment where both technlogy and social skills can be achived as well as the necessary learning goals. In many schools students condition are commonly heterogen. By heterogen it means there are difference in sex, religious believe,social status, academic skills, and race.

The aim of cooperative model is to improve students' academic learning achievement and students can accept diversity from their classmates, also the development of social skills. In cooperative learning discussion and communication is established among several person that enable both verbal and noverbal response. The aim of this communication is for students to share their skills, excercise critical thinking, giving opinions, learning together, and giving assesment on each other skill.

Based on the explanation above, the writer proposes a reasearch entitled the effect of Team Assisted Individualization model (TAI) on students' ecology learning outcome and their interpersonal communication skill. Research question are formulated as follows 1) is there any effects of Team Assisted Individualization model on 
students' ecology achievement; and 2) Is there any effect of Team Assisted Individualization model on students' interpersonal communication skill?

According to Nana [1] achievement is realization of one's potential skill or capacity. Mastery of achievement can be seen through students' attitude such as knowledge mastery, thinking skill and motorist skill. Almost all activities or attitude is a result of learning process. In order to get complete learning achievement, there are three aspects that need to be address they are cognitive, affective, and psychomotor.

As well as intelegence, talent and learning achievement can also be measured. The tool used in measuring learning achievement is called achievement test. Achievement test mostly compiled by teachers for every subject in all semester, at the very least there would be one test for every semester.

According to Odum, [2] Ecology is the study of reciprocate relationship between living being and their environment. Living being in farming is plant, while the environments are water, land, humus, and others. The word ecology itself comes from two words from Greek, which is oikos and logos. Oikos means home or place for living, while logos mean study or the knowledge. Therefore originally ecology means "the study of organism in their place of living". Generally what is meant by ecology is "the study of reciprocate relationship between organism or a group of organism and their environment." Nowadays, ecology much refers to "the study of structure and function of nature." Moreover it is said to be the study of organism household.

According to Zoer'aini [3], someone who studies about ecology is actually questioning many things from: 1 . How nature works 2. How a species adapt in their habitat 3 . What is needed by organism to live 4. How an organism fulfill their need for energy and mater 5. How do species interact among themselves in an environment 6. How individual species arranged and work as population.

Communication skill according to Friedrich in A. Pelani [4] is perceived as the situational ability to achieve desirable goal by improving communication skill through self knowledge, others, context and communication theory so that it can be generalized in adapative communication act.

One of the types of communication is interpersonal communication or face to face communication among several person which enable both verbal and nonverbal response. Operationally communication happens with feedback from a message. Communication that happens in two ways and have feedback will ensure effective communication.

According to William and Melissa [5] (Sixth edition) interpersonal communication is a process of exchanging information between two people or more. The information is gain through interaction between those people communicate.

Interpersonal communication skill is a skill in processing information done by two people or more and personal which happens both directly (without medium) and indirect (through medium).
According to Johnson \& Johnson [6] cooperative learning is a way of learning through groups so that students can learn together to achieve group goal. In cooperative learning students discuss and help each other in understanding material. According to Ahmad [7] there are several types of cooperative learning, such as: Jigsaw, Field Study, Team Assisted Individualization, Team Game Tournament (TGT), Student Teams Achievement Division (STAD), Numbered Heads Together (NHT).

According to Sholomo [8] Team Assisted Individualization is a model developed by Slavin, Leavy, dan Madden altogether at John Hopkins University which combine cooperative activity and individual learning.

Typically on Team Assisted Individualization every students, individually study the material which prepared by the teacher. The result of individual learning is taken into groups and discusses by group members. All members of the group are responsible for the answer.

According to Richard I. Arends [9] in Jigsaw, each member of a group is responsible to master one part of the material and to teach it to other members in the same team. In accordance with that, according to Ahmad [7] the upper hand of Jigsaw is that this method involves all students in learning and also shares it to others

\section{RESEARCH METHODS}

This research is aimed at finding out if there are any effects of Team Assisted Individualization model on students ecology achievement and their interpersonal communication skill. Experimental method is used in this research. There is one independent which is cooperative learning using variable on this research Team Assisted Individualization model and two dependent variables which are ecology achievement and interpersonal communication skill. The sample in this research is students of biology education study program, FKIP Unpak, the fourth semester. The samples are two classes, they are class IV A as the experimental group taught using Team Assisted Individualization model and class IV $\mathrm{B}$ as the control group taught using Jigsaw.

Data analysis is done both descriptively and inferentially. Inferential analysis is done to test the hypothesis and significance. Before analyzing the hypothesis, preliminary test were done through normality test and homogeneity

\section{RESULTS AND DISCUSSION}

The research result covers data description of the result, preliminary analysis test, hypothesis testing, and interpretation of the research result.

Research result description is categrorized into four parts, consist of dua parts of dependent variables which are students' ecology achievement from experimental group and control group and two parts of dependent variables which 
are interpersonal communication skill of the experimental group and contorl group.

Preliminary analysis of the research data is done through $\mathrm{t}$ test for testing the hypothesis. Before conducting data analysis, hypothesis preliminary test is done, thorugh normality and homogenity test. The result of normality test can be seen in the table 1 .

Table 1 . Normality test result

\begin{tabular}{|c|l|c|c|c|}
\hline No & \multicolumn{1}{|c|}{$\begin{array}{c}\text { Treatment Group } \\
\text { Distribution }\end{array}$} & $\mathrm{X}^{\mathbf{2}}$ test & $\mathrm{X}^{\mathbf{2}}$ table & Conclusion \\
\hline 1 & $\begin{array}{l}\text { Students' ecology achivement } \\
\text { experimental group }\end{array}$ & 2,88 & 11,3 & $\begin{array}{c}\text { Normal } \\
\text { Distribution }\end{array}$ \\
\hline 2 & $\begin{array}{l}\text { Students' ecology achivement } \\
\text { control group }\end{array}$ & 7,3 & 11,3 & $\begin{array}{c}\text { Normal } \\
\text { Distribution }\end{array}$ \\
\hline 3 & $\begin{array}{l}\text { Students' interpersonal } \\
\text { communication skill } \\
\text { experimental group }\end{array}$ & 6,3 & 11,3 & $\begin{array}{c}\text { Normal } \\
\text { Distribution }\end{array}$ \\
\hline 4 & $\begin{array}{l}\text { Students' interpersonal } \\
\text { communication skill control } \\
\text { group }\end{array}$ & 10,55 & 11,3 & $\begin{array}{c}\text { Normal } \\
\text { Distribution }\end{array}$ \\
\hline
\end{tabular}

Homogeneity test is done using chi square. The result of the homogeneity variable of ecology learning achievement is shown table 2 .

Table 2. Homogeneity Test for Students' Ecology Achievement

\begin{tabular}{|l|c|c|c|c|c|}
\hline $\begin{array}{c}\text { Treatment Group } \\
\text { Distribution }\end{array}$ & Db & $1 / d b$ & $\mathbf{S i}^{2}$ & Log S & $\begin{array}{c}\text { dlb. Log } \\
\mathbf{S}^{2}\end{array}$ \\
\hline $\begin{array}{l}\text { Students' ecology } \\
\text { achivement } \\
\text { experimental group }\end{array}$ & 38 & 0,0263 & 286,15 & 2,4566 & 93,3508 \\
\hline $\begin{array}{l}\text { Students' ecology } \\
\text { achivement control } \\
\text { group }\end{array}$ & 35 & 0,0286 & 180,82 & 2,5725 & 90,0375 \\
\hline \multicolumn{1}{|c|}{ Total } & 73 & & & & $\mathbf{1 8 3 , 3 8 8 3}$ \\
\hline
\end{tabular}

Homogenity test for interpersonal communication variable is checked using chi square, and the data is shown table 3 .

Table 3. Homogenity test for interpersonal communication skill

\begin{tabular}{|l|c|c|c|c|c|}
\hline $\begin{array}{c}\text { Treatment Group } \\
\text { Distribution }\end{array}$ & $\mathbf{D b}$ & $1 / d b$ & $\mathbf{S i}^{2}$ & $\mathbf{L o g} \mathbf{S i}^{\mathbf{2}}$ & $\mathbf{d l b .} \mathbf{L o g} \mathbf{S i}^{\mathbf{2}}$ \\
\hline $\begin{array}{l}\text { Students' } \\
\text { interpersonal } \\
\text { communication skill } \\
\text { experimental group }\end{array}$ & 38 & 0,0263 & 141,99 & 2,1523 & 81,7874 \\
\hline $\begin{array}{l}\text { Students' } \\
\text { interpersonal } \\
\text { communication skill } \\
\text { control group }\end{array}$ & 35 & 0,0286 & 97,91 & 1,9908 & 69,678 \\
\hline \multicolumn{1}{|c|}{ Total } & $\mathbf{7 3}$ & & & & $\mathbf{1 5 1 , 4 6 5 4}$ \\
\hline
\end{tabular}

After the data is considered normal and homogen, the next step is to test the hypotehsis. Hypothesis test is done to find out whether proposed null hypothesis (Ho) is accpeted or rejected. In testing the null hypothesis (Ho) t test is used.

The first null hypothesis test (Ho1) is done by calculating the $\mathrm{N}$-gain score of students' ecology achievement between experimental group and control group by comparing the result of pre-test and post-test of each group. The result is shown below.

Table 4. Recapitulation Of Students' Ecology Achievement

\begin{tabular}{|c|c|c|c|c|c|}
\hline \multirow{2}{*}{ Group Class } & \multirow{2}{*}{$\mathbf{N}$} & \multicolumn{2}{|c|}{ Skor \% } & \multirow{2}{*}{$\begin{array}{c}\text { N-Gain } \\
\text { \% }\end{array}$} & $\begin{array}{c}\text { Understanding } \\
\text { criteria }\end{array}$ \\
\cline { 3 - 4 } & & Pre-test & Post-test & & \\
\hline Eksperimental & 39 & 41,67 & 70,23 & 18,68 & \\
\hline Control & 36 & 37,78 & 56,14 & 10,59 & \\
\hline
\end{tabular}

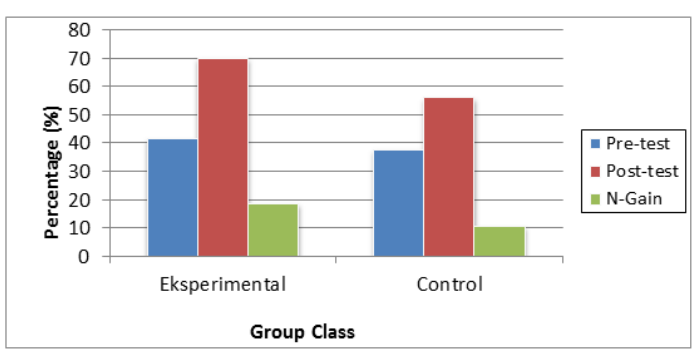

Figure 1. Histogram Of Students' Ecology Acheivement

Based on the data of $\mathrm{N}$-Gain for experimental group is $18,68 \%$ while control group is $10,59 \%$. Then, $t$ test is calculated on significance level of $\alpha=0,05$ and the score for $\mathrm{t}_{\text {observation }}\left(\mathrm{t}_{\mathrm{o}}\right)=21,9$ and the value of $\mathrm{t}_{\text {table }}=1,67$ the value of $\mathrm{t}_{\text {observasi }}\left(\mathrm{t}_{\mathrm{o}}\right)>\mathrm{t}_{\text {tabel }}$ it mans that the first null hypothesis $\left(\mathrm{H}_{\mathrm{o}} 1\right)$ is rejected and alterbative hypothesis $\left(\mathrm{H}_{\mathrm{a}} 1\right)$ is accepted. It can be concluded from the result that all and all students ecology achievement in experimental group is better than those in control group.

The second null hypothesis (Ho2) is tested using $\mathrm{N}$ gain calculation fro interpersonal communication skill between experimental group and control group. The score is compared from the result of pre-test and post-test result for each group. The table and histogram below show the result of pre-test and post-test.

Table 5. Recapitulation Of Students' Interpersonal Communication Skill

\begin{tabular}{|c|c|c|c|c|c|}
\hline \multirow{2}{*}{ Group Class } & \multirow{2}{*}{ N } & \multicolumn{2}{|c|}{ Score\% } & \multirow{2}{*}{ N-Gain } & Understanding \\
\cline { 3 - 4 } & & Pre-test & Post-test & $\%$ & criteria \\
\hline Eksperimental & 39 & 88 & 93,92 & 7,73 & \\
\hline Control & 36 & 86,44 & 91,22 & 5,49 & \\
\hline
\end{tabular}

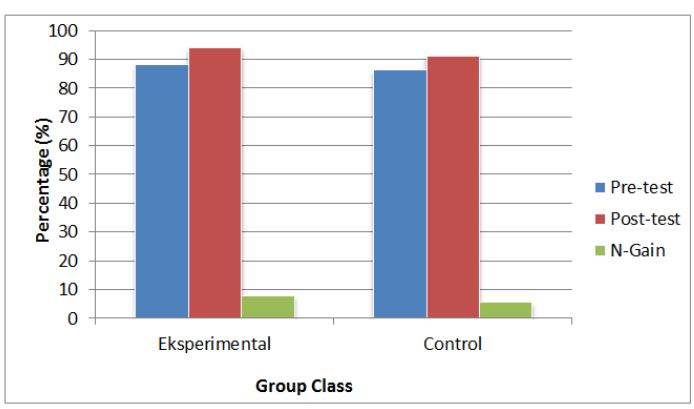

Figure 2. Histogram For Students' Interpersonal Communication Skill Score 
Based on the data bove, N-Gain value of experimental group is higher than the control group, which are 7.73 to 5.49 the next step is testing the $t$ test on significance level of $\square=0,05$ and come up with tobservation (to) value $=13,86$ and the value of ttable $=1,67$ which can be said that tobservation (to) $>$ ttable. It can be concluded that the second null hypothesis (Ho2) is rejected and the second alternative hypothesis ( $\mathrm{Ha} 2)$ is accepted. It can be concluded from the result that all and all students' interpersonal communication skill om experimental group is better than those in control group. The calculation can be seen in the table 6.

Table 6. Null hypothesis testing

\begin{tabular}{|c|c|c|}
\hline $\begin{array}{c}\text { Null Hypothesis } \\
\mathrm{H}_{\mathrm{o}}\end{array}$ & $\mathrm{t}_{\text {observation }}\left(\mathrm{t}_{\mathrm{o}}\right)$ & $\mathrm{t}_{\text {table }}\left(\mathrm{t}_{\mathrm{t}}\right)$ \\
\hline $\mathrm{H}_{\mathrm{o}} 1$ & 21,9 & 1,67 \\
\hline $\mathrm{H}_{\mathrm{o}} 2$ & 13,86 & 1,67 \\
\hline
\end{tabular}

Based on the research result, the average score of students' ecology achievement between the two samples is collected. The experimental group which was taught using Team Assisted Individualization model has better score compared to the control group which was taught using Jigsaw model. It can be seen through the result of pre-test and post-test given to experimental group which was taught using Team Assisted Individualization model from 39 students the average score is 47,64 . While on the control group which taught using Jigsaw from 36 students the score is 29,42.

Based on the result for the interpersonal communication skill the average score for both group is collected. Experimental group which taught using Team Assisted Individualization model shows good result compared to control group which taught using Jigsaw, even though it Is not significant. It can be seen through the calculation of N-Gain done to experimental group from 39 students the average score is 19,5 while for control group from 36 students the average score is 15,3.

Interpersonal communication skill can be improved when students understand how to communicate better during group discussion in class.

One of the characteristic of cooperative learning is direct interaction it means that students verbal communication should be supported to establish positive feedback on their achievement. Students should help each other and share their thought in order to solve problem given during teaching learning process. Moreover, students should develop effective communication skill to support their learning process in the classroom either with teacher or with other students.

Both in experimental and control group, students posed as peer teacher for their friends. It is because in cooperative learning there is a form of motivation and assignments that can make students interact with their friends. In cooperative learning students are taught special skills so that they can work effectively in the group, such as becoming active listener, giving explanation to group mate. Furthermore one of the other characteristic is interpersonal and small group skill. Based on the explanation above, it can be said that cooperative model has the characteristic as an interpersonal and small group skill. Therefore, the average score of interpersonal communication skill will not be so much different.

\section{CONCLUSION}

Based on the result and data analysis, it can be concluded that: 1) the use of Team Assisted Individualization model in teaching learning biology has better effect on students' ecology achievement compared to Jigsaw. It can be seen from the first null hypothesis test where $t_{\text {observation }}$ is bigger than $t_{\text {table }}$ which means research hypothesis is accepted. Beside that the average score of students' ecology achievement for experimental group is higher that the control group; and 2) the use of Team Assisted Individualization model in teaching learning biology has better effect on students; interpersonal skill compared to Jigsaw. It can be seen through the second hypothesis test where $t_{\text {observation }}$ is bigger than $t_{\text {table }}$ which means research hypothesis is accepted. It also supported by the average score of interpersonal communication skill where the experimental group got higher score than the control group.

\section{REFERENCES}

[1] Nana, Syaodih Sukamdinata,. 2007. Landasan Psikologi Proses Pendidikan. Bandung: Rosda Karya

[2] Odum, Eugene P. 1996. Dasar-Dasar Ekologi. Yogyakarta: Gajah Mada University Press

[3] Zoer'aini, Irwan, Djamal. 2007. Prinsip-prinsip Ekologi, Ekosistem, Lingkungan dan Pelestariannya. Jakarta: Bumi Aksara

[4] Pelani, Ahmad. 2008. Kecakapan Berkomunikasi. Jakarta: UNJ

[5] William, Seiler, J. and Mellisa L. Beall. Sixth Edition. Communication Making Connections. Sydney

[6] Johnson, David W. and Roger T. Johsnson. 1991. Learning Together and Alone. America: Prentice Hall

[7] Suwarno, Ahmad. 2008. Pembelajaran Kooperatif Universitas Veteran Bangun Nusantara

[8] Sholomo, Sharan,. 2009. Handbook of Cooperative Learning. Yogyakarta: Imperium

[9] Arends, Richard I. 2008. Learning to Teach (Belajar Untuk Mengajar), Edisi Ketujuh. Yogyakarta: Pustaka Belajar. 